\title{
The Intention to Use E-Money: An Empirical Study of Halal Food SMEs In Surakarta
}

\author{
Yulfan Arif Nurohman $^{1 *}$, Rina Sari Qurniawati ${ }^{2}$ \\ ${ }^{1}$ Fakultas Ekonomi dan Bisnis Islam, UIN Raden Mas Said Surakarta \\ ${ }^{2}$ STIE AMA Salatiga
}

\begin{abstract}
Entering Financial Technology (FINTECH) era, Indonesian Banks and financial institutions competing in issuing their electronic money product. E-money potentially used by Small and Medium Enterprises (SMEs) for doing business and making transactions but in reality it is not so. Halal food SMes E-money usage still low so its important for fintech companies to be able to know and understand perceptions to increase interest in re-transacting using electronic money. However, these is still few studies discussed behavioral intention to use e-money in SMEs sector. Consequently, This study identifies and examines the factors that contribute to behavioral intention to use e-money in Surakarta from the Halal food SMEs perspective . Data for this study were obtained through a mail survey sent to 125 Halal Food SMEs in Surakarta, Jawa Tengah. Regression is used to analyze the data and determine the impact the factors have on behavioral intention to use e-money. The regression results confirm that perceived usefulness, perceived ease of use, perceived behavioral control are the most likely factors that contribute to halal food SMEs intention to use e-money whereas trust was not significantly related. Implications of the findings for developers are discussed further.
\end{abstract}

Keywords: e-money, halal food SMEs, Behavioral Intention

\section{Introduction}

Transactions are activities that can't be separated from human life. In transactions, each individual also requires some payment in the form of money. The use of money which has become a necessity has made develop very rapidly in the past years. Starting from the type of money to the emergence of a system that regulates finances. These developments can't be separated from the rapid development of technology changes so payment model become faster, more efficient and more flexible. In various countries, non-cash payment systems are being intensively developed. The high amount of money circulating in the market led to the emergence of counterfeiting cases, and the more costs that had to be incurred for the operations of printing, storing and distributing cash by the central bank. Technological developments in the Industrial revolution 4.0 era have created intense competition in the business world, both large companies and SMEs. The businessman are required to have the

\footnotetext{
* Corresponding author: yulfanan@gmail.com
} 


\section{$A I C \overline{I E B}$ Annual International Conference \\ on Islamic Economics and Business, 2021}

ability to think creatively and innovatively in order to survive in business competition. Small and medium enterprises of SMEs must also follow the IT development so that their business running smoothly. Currently, SMEs continue to be targeted to use this technology or they being targeted to be digitized. Currently, there are still many small and medium industry players (SMES) in Surakarta who do not understand e-commerce schemes. This is anticipated by the successful training of Entrepreneurs in the Digital Era conducted by Bank Indonesia which was attended by almost 350 SMEs in Surakarta. This training aims to introduce SMEs to various digital media as business instruments.

The huge potential of the halal culinary market is a great opportunity for Indonesian SMEs. Indonesia itself is a country with the largest Muslim population in the world, so the market for halal food products is wide open. With this opportunity, Indonesian SMEs must be able to become a major player in halal products both in the domestic and foreign markets. In the perspective of sharia itself, electronic money has a halal legal basis. This law is based on a rule where every transaction in muamalah is basically allowed unless there is a proposition that prohibits it, then at that time the law turns into haram. now is the era of the industrial revolution 4.0, namely the era of using technology and information so that SMEs must adapt to the various changes that exist if they do not want to be left behind (Sari \& Santoso, 2019).

The emergence of e-commerce in recent years has led to another innovation, that is the online payment system. Now there are several electronic money-based online payment service providers, such as Shopee Paylater, Dana, Ovo, Go-Pay, and others. By using Emoney, SMEs actors will get some compared to when using other non-cash payments such as easier and faster. However, electronic money is less popular because of the lack of public understanding. For SMEs who are not familiar with the e-money, this is a more troublesome thing than using cash. Several attempts were made by Bank Indonesia to increase interest in using e-money but low level of non-cash transactions occurs in halal Food SMEs in Surakarta.

Generally, SMEs actors still choose to transaction with cash because the benefits and convenience of electronic money are still not felt. People's decisions in using electronic money facility services are influenced by information on electronic money instruments obtained. One of the influencing factors is the perceived usefulness, which is the extent to which the level of profit obtained using electronic money instruments (Davis, 1989). A service that is able to provide many benefits to consumers will be more likely to be well received in society.

Intention to use e-money is also influenced by the perceived ease of use. Many people consider the use of electronic money because of the complicated transaction system which requires additional tools compared to conventional transactions using cash. According to Jogiyanto (2007) perceived ease of use is determined by how much effort is used to use an instrument, where the smaller the effort expended, the easier the instrument is to use.

Theory of Planned Behavior (TPB) was proposed and developed by Ajzen (1991) which is a development of the Theory Reasoned Action (TRA) previously proposed by Fishbein and Ajzen (Ajzen \& Fishbein, 1970). TPB provides a systematic framework for investigating what factors influence a person to do something (influence a person's behavior) and this theory has been widely applied in various fields of behavioral science. Based on the TPB model, a person's behavior is a function of intention, where a person's intention is formed from the presence of attitudes, subjective norms, and perceived behavioral control. Perceived behavioral control is the SMEs actor's subjective perception of how easy or difficult conducing e-money from FINTECH companies. In general, perceived behavioral control have an important technology and its role has been confirmed from previous studies (Khatimah \& Halim, 2016; Taylor \& Todd, 1995). 


\section{$A I C \overline{I E B}$ Annual International Conference \\ on Islamic Economics and Business, 2021}

In addition, the trust factor in the product also affects the use of electronic money services. Trust is the willingness to rely on others to do something (Kotler and Keller, 2016). Trust is important for electronic money as a transaction tool used. This concept of trust means the reliability of the electronic money service provider in ensuring the security and confidentiality of the instruments used by consumers to make consumers trust.

\section{Literature Review}

Electronic money or often called digital money is a tool used to store electronic money by using internet transactions on technical devices. Electronic money also has stored value or prepaid where all the amount of money is stored in electronic media owned by a person. The value of electronic money will decrease when transactions are made to consumers. Electronic money can be used for various types of payments (multipurpose). Electronic money is an innovative and practical means of payment so that it can make payments easier (Firmansyah, 2018). Electronic money (e-money) according to Bank Indonesia Regulation No. 20/6 / PBI / 2018 concerning Electronic Money is a payment instrument that fulfills the following elements, first, it is issued on the basis of the value of money that is previously determined by the holder to the issuer. Second, values are stored electronically in a medium such as a server or chip. Third, the value of electronic money deposited by the holder and managed by the issuer is not referred to in the law governing banking.

Electronic money has several advantages compared to cash or other non-cash payment instruments, that is faster and more convenience. In Islam, the law of change is described in surah An-Nisa verse 29, Allah Say "O you who have believed, do not consume one another's wealth unjustly but only [in lawful] business by mutual consent. And do not kill yourselves [or one another]. Indeed, Allah is to you ever Merciful". From the Surah, Muslim entrepreneurs who use e-money in transactions can apply Islamic practices in accordance with the Al-Quran.

\subsection{Intention to Use E-Money}

According to Davis et al. (1989) The intention or behavior intention is defined as the degree to which a person's desire or motivation is strong to do a certain thing. Motivation, perception, belief and attitude are psychological factors that influence consumer decisions. This factor can influence the decision making, giving rise to the intention of someone to do it. Intention is a urge that is driven by a desire after seeing, observing and comparing and considering the desired needs (Seng \& Ping, 2016). Consumer interest in innovative products can be analyzed by looking at the internal and external sides of the product. The internal side, where it depends on the knowledge, capacity, resources and technology used in the company while the external side is the needs of consumers and the owner's expectations of the company's products.

Purchase intention is a consumer's plan to buy one or more of a product that is needed within a certain period. It can be said that interest is a mental statement from consumers that reflects to make a purchase of a particular product. Behavioral intention has been widely studied before which discusses the acceptance of technology in the payment system (AbdulHamid et al., 2019; Khatimah \& Halim, 2016; Prayitno, 2018).

\subsection{Perceived Usefulness}

Perceived usefulness is defined as where a person believes that using a technology will improve his work performance (Jogiyanto, 2007). From the definition, it is known that the perception of benefits is a belief about the decision-making process. The easier it is to use, 


\section{$A I C \overline{I E B}$ Annual International Conference \\ on Islamic Economics and Business, 2021}

the higher the confidence in using technology in completing work and very beneficial for survival (Made et al., 2016).

Perceived usefulness is the subjective probability of potential users using a particular application to facilitate the performance of their work (Romadloniyah \& Prayitno, 2018). This streamlined performance can produce more advantages both in terms of physical and non-physical, such as the results obtained will be faster and with more satisfying results compared to not using the new technology of the product.

According to Davis et al., (1989) it is stated that users have confidence if using an information system it will improve performance. That is, the perception of usefulness will result in a belief to make decisions by using the information system or not using it. Users will think and believe that if the system is useful for him, he will use it. So on the contrary if the system is not useful then the user will not use it.

\section{H1: Perceived usefulness positively affect Halal Food SMEs intention to Use E-Money}

\subsection{Perceived Ease of Use}

Davis et al. (1989) stated that perceived ease of use is the extent to which a person believes that using a technology will be effort-free. From the definition, it can be seen that the perception of ease is a belief about the decision-making process. If someone believes that the information system is easy to use then he will use it. Ahmad \& Pambudi (2013) interpreted the perception of ease of use as an individual's belief that using an information technology system would not be troublesome or require great effort when used (free of effort). This perception of ease of use will be formed when users reach a level where they believe that the technology/system can be used easily and problem-free.

The dimensions of perceived ease are, ease to learn, ease to use, clear and understandable), and become skillful (Wibowo et al., 2015). Ease means not finding difficulties or not requiring a large amount of effort when using the technology. Thus the perception of the ease of use of this technology refers to the individual's belief that the information technology system used does not require great effort during operation. According to Ramadhan et al., (2016) ease of use has a positive effect on interest in using electronic money.

\section{H2: Perceived ease of use positively affect Halal Food SMEs intention to Use E-Money}

\subsection{Perceived Behavioral Control}

The theory that is widely used in various fields of behavioral science is the Theory of Planned Behavior (TPB) which is a systematic framework that studies what factors influence a person to do something (Tonglet et al., 2004). Based on the TPB model, a person's behavior is a function of intention, which intention is formed by attitudes, subjective norms, and perceived behavioral control (Ajzen, 1991)

Perceived behavioral control (PCB) in Theory of Planned Behavior as a person's perception of obstacles in performing a behavior (Terry \& O'Leary, 1995). PCB is a factor that represents a person's actual control over his behavior. This arises from the level of subjective control over a behavior performance when someone assesses the ease or difficulty of performing the behavior (Ajzen, 2006). According to Ajzen \& Fishbein (1975) there are two aspects of PBC that is control beliefs and power to control. Control Beliefs are individual control beliefs about the amount of self-control on behavior in preventing or facilitating the behavior you want to display. Power to Control which is the magnitude of the individual's role in the realization of behavior. 


\section{$A \mathrm{C} \overline{I E B}$ Annual International Conference \\ on Islamic Economics and Business, 2021}

In general, perceived behavioral control have an important technology and its role has been confirmed from previous studies (Khatimah \& Halim, 2016; Taylor \& Todd, 1995).

H3: Perceived behavioral control positively affect Halal Food SMEs intention to Use EMoney

\subsection{Trust}

According to Jogiyanto (2007) trust represents cognitive structures developed by individuals after collecting, processing, and synthesizing information, and including individual judgments from various related outcomes. Meanwhile, according to Ba \& Pavlou, (2002), Trust is defined as an assessment of the relationship between a person and another person who will carry out a transaction in accordance with expectations in an environment full of uncertainty.

Trust is the basis for transactions for sellers and buyers which makes consumers have high hopes for being satisfied with the exchange relationship. Trust in Electronic e-money determines consumer decisions to engage in e-commerce business provider relationships. With the emergence of many online crimes, the future of e-commerce will rely on consumer confidence in the web and internet technology (Widyastuti et al., 2017). According to experts, it can be said that trust is a psychological state to receive information after it has been collected and then take action. With this trust, the relationship between parties will maintain the interests, commitments, and provide services and benefits for others.

\section{H4: Trust positively affect Halal Food SMEs intention to Use E-Money}

\section{Method}

This research is a descriptive study that aims to provide an overview of a research subject from the data variables obtained from the subject under study and used to test hypotheses. In this study, Halal food SMEs in Surakarta were selected as the survey respondents, who were over 17 years old and use e-money as transaction tools. The survey will be conducted by only choosing SMEs that sell halal food. Self-administered questionnaires are distributed in two ways, first is filling in on paper and second via google form with hyperlinks sent by WhatsApp to the respondents, The sampling method in this research is non probability sampling with purposive sampling

Measurements for each construct of this study were derived from previous studies. Each question item in the questionnaire was measured using five Likert scales, ranging from strongly disagree (1) to strongly agree (5). The data analysis method in this study uses multiple linear regression analysis with SPSS Software as the tools used to find the relationship between variables.

As previously mentioned, in analyzing the data in this study, multiple regression analysis was used. Multiple regression analysis formulation can be seen in the formula below :

$$
\mathrm{Y}=\mathrm{a}+\mathrm{b} 1 \mathrm{X} 1+\mathrm{b} 2 \mathrm{X} 2+\mathrm{b} 3 \mathrm{X} 3+\mathrm{b} 4 \mathrm{X} 4
$$

Information :

$\mathrm{Y}=$ Intention to use E- Money (Y)

$\mathrm{a}=$ Constant

$\mathrm{X} 1$ = Perceived Usefulness

$\mathrm{X} 2=$ Perceived Ease of Use 


\section{A IC $\overline{I F B}$ Annual International Conference \\ on Islamic Economics and Business, 2021}

$\mathrm{X} 3=$ Perceived Behavioral Control

$\mathrm{X} 4=$ Trust

b1, b2, b3, b4 = Regression Coefficient

Table 1. Operational Translation

\begin{tabular}{|c|c|}
\hline Variable & Indicator \\
\hline Intention to use E- Money (Y) & $\begin{array}{l}\text { 1. Using e-money for transaction payment. } \\
\text { 2. In the future still using e-money } \\
\text { 3. Using e-money for transaction payment can make the } \\
\text { life easier } \\
\text { 4. Other people have to use e-money } \\
\text { 5. E-money is very practical, saves time and effort, and } \\
\text { provides future benefits } \\
\text { 6. There are many advantage using e money }\end{array}$ \\
\hline Perceived Ease of Use & $\begin{array}{ll}\text { 1. } & \text { Work more quickly } \\
\text { 2. } & \text { Job performance } \\
\text { 3. } & \text { Increase Productivity } \\
\text { 4. } & \text { Effectiveness } \\
\text { 5. } & \text { Makes Job easier } \\
\text { 6. } & \text { Useful } \\
\end{array}$ \\
\hline Perceived Usefulness & $\begin{array}{ll}\text { 1. } & \text { Easy to Learn } \\
\text { 2. } & \text { Easy to Use } \\
\text { 3. } & \text { Easy to Understand } \\
\end{array}$ \\
\hline Perceived Behavioral Control & $\begin{array}{l}\text { 1. Able to use e money for transactions } \\
\text { 2. Individual control to using e-money } \\
\text { 3. have the resources, knowledge, and ability to use e- } \\
\text { money in my mobile }\end{array}$ \\
\hline Trust & $\begin{array}{l}\text { 1. Trust in conducting banking transactions via the internet } \\
\text { 2. Maintain the interests of customer transactions } \\
\text { 3. Maintain commitment to serve customers } \\
\text { 4. Provide benefits for users during transactions }\end{array}$ \\
\hline
\end{tabular}

\section{Data Analysis and Result}

Data of 125 respondents were collected and by using the method of multiple linear regression, the model was analysed by using the software of SPSS statistical software version 25 . As seen from table 1 , all the questions on the questionnaire are able to reveal something that will be measured in this study or in other words are valid. In this case, it can be proven by all the calculated $r$ values greater than the table $r$ values.

Tabel 2. Validity Analysis

\begin{tabular}{|l|l|l|l|}
\hline \multicolumn{1}{|c|}{ Item } & \multicolumn{1}{c|}{ rhitung } & \multicolumn{1}{c|}{ rtabel } & Hasil \\
\hline PU1 & 0.819 & 0.172 & Valid \\
\hline PU2 & 0.558 & 0.172 & Valid \\
\hline PU3 & 0.842 & 0.172 & Valid \\
\hline PU4 & 0.868 & 0.172 & Valid \\
\hline PU5 & 0.776 & 0.172 & Valid \\
\hline PU6 & 0.698 & 0.172 & Valid \\
\hline PEU1 & 0.801 & 0.172 & Valid \\
\hline PEU2 & 0.806 & 0.172 & Valid \\
\hline PEU3 & 0.767 & 0.172 & Valid \\
\hline PEU4 & 0.815 & 0.172 & Valid \\
\hline PEU5 & 0.866 & 0.172 & Valid \\
\hline
\end{tabular}




\section{$A I \overline{I E B}$ Annual International Conference on Islamic Economics and Business, 2021}

\begin{tabular}{|l|l|l|l|}
\hline PCB1 & 0.855 & 0.172 & Valid \\
\hline PCB2 & 0.913 & 0.172 & Valid \\
\hline PCB3 & 0.907 & 0.172 & Valid \\
\hline TRT1 & 0.750 & 0.172 & Valid \\
\hline TRT2 & 0.695 & 0.172 & Valid \\
\hline TRT3 & 0.851 & 0.172 & Valid \\
\hline TRT4 & 0.887 & 0.172 & Valid \\
\hline TRT5 & 0.847 & 0.172 & Valid \\
\hline INTENTION1 & 0.867 & 0.172 & Valid \\
\hline INTENTION2 & 0.794 & 0.172 & Valid \\
\hline INTENTION3 & 0.849 & 0.172 & Valid \\
\hline INTENTION4 & 0.776 & 0.172 & Valid \\
\hline INTENTION5 & 0.807 & 0.172 & Valid \\
\hline INTENTION6 & 0.861 & 0.172 & Valid \\
\hline
\end{tabular}

All variable items used are reliable, which means that each variable item has an Alpha Coefficient value of more than 0.06 as shown in table 3 . This means that this measuring instrument is able to produce reliable data.

Table 3. Reliability Analysis

\begin{tabular}{|l|c|l|}
\hline \multicolumn{1}{|c|}{ Variable } & Cronbach's Alpha & Result \\
\hline Perceived Usefulness (X1) & 0.852 & Reliable \\
\hline Perceived Ease of Use (X2) & 0.868 & Reliable \\
\hline Perceived Behavioral Control (X3) & 0.870 & Reliable \\
\hline Trust (X4) & 0.861 & Reliable \\
\hline Intention to Use E-Money (Y) & 0.905 & Reliable \\
\hline
\end{tabular}

$\mathrm{R}=0.738 \mathrm{R}^{2}=0.544 \mathrm{~F}_{\text {statistics }}=35.806$

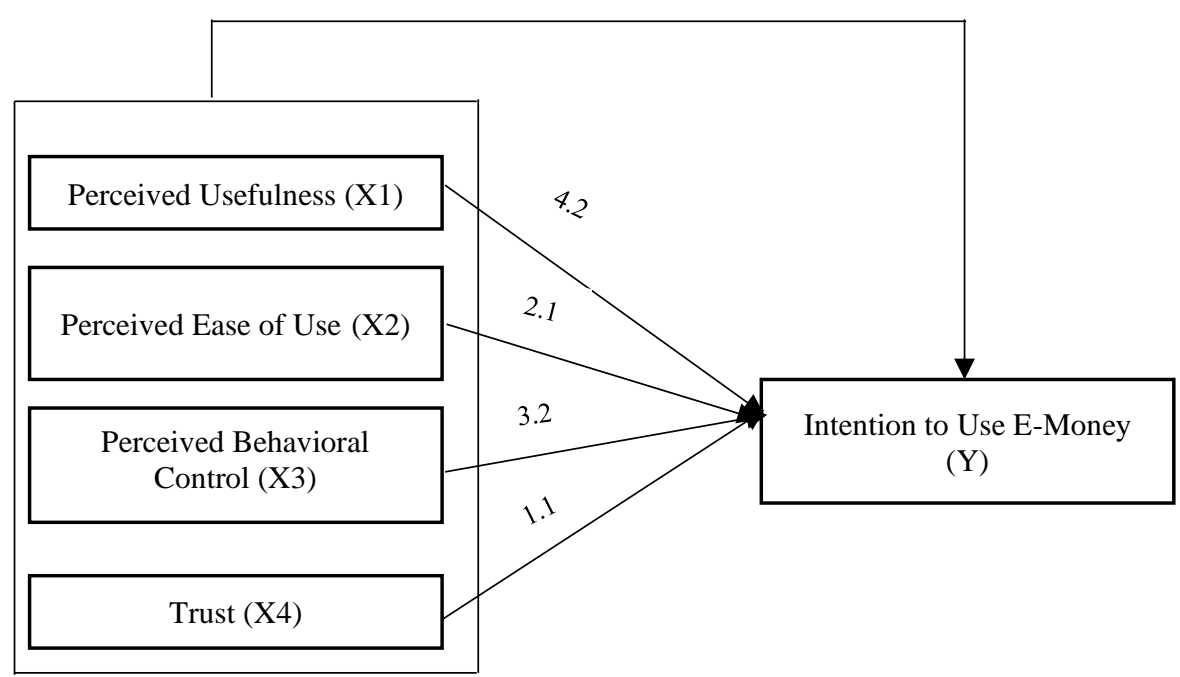

Fig 1. Outcome of Multiple Regression Analysis 


\section{$A I \overline{I F B}$ Annual International Conference \\ on Islamic Economics and Business, 2021}

Table 4. The Result of Regression

\begin{tabular}{|c|l|c|c|}
\hline \multicolumn{1}{|c|}{ Hypothesis } & Sig. & Decision \\
\hline H1 & $\begin{array}{l}\text { Perceived usefulness positively affect } \\
\text { Halal Food SMEs intention to Use E- } \\
\text { Money }\end{array}$ & 0.000 & Not Rejected \\
\hline H2 & $\begin{array}{l}\text { Perceived ease of use positively affect } \\
\text { Halal Food SMEs intention to Use E- } \\
\text { Money }\end{array}$ & 0.003 & Not Rejected \\
\hline H3 & $\begin{array}{l}\text { Perceived Behavioral Control positively } \\
\text { affect Halal Food SMEs intention to Use } \\
\text { E-Money }\end{array}$ & 0.001 & Not Rejected \\
\hline H4 & $\begin{array}{l}\text { Trust positively affect Halal Food SMEs } \\
\text { intention to Use E-Money }\end{array}$ & 0.252 & Rejected \\
\hline
\end{tabular}

Note: *Significant at 0.05

From the result in table 4 above, it can be seen that 3 hypotheses are supported i.e. perceived usefulness, perceived ease of use, and perceived behavioral control positively affect halal food SMEs intention to use E-Money. Whereas, trust has positive and not significant influence to the halal food SMEs intention to use E-Money.

\section{Discussion}

The result show that Perceived usefulness positively affect halal food SMEs intention to Use E-Money $(\beta=0.413, \mathrm{t}=4.282$, sig $<0.05)$. So it can be concluded that the Perceived usefulness affects the interest of halal food SMEs actors in using electronic money as payment tools in Surakarta. Based on the facts, halal food SMEs actors who feel the benefits of using electronic money will increasingly use electronic money. The higher the benefits of electronic money, the higher the interest of SMEs in using electronic money. The results supported by (Made et al., 2016; Prayitno, 2018; Priambodo \& Prabawani, 2016) that the Perceived usefulness has a positive effect on customer interest to use e-money. This research strengthens this research that if the perceived benefits are greater, then halal food SMEs actors will do it as a tools of payment. Halal food SMEs actors who feel great benefits in using electronic money will have a greater desire to use electronic money. The higher the benefits of electronic money, the higher the interest of SMEs in using electronic money

The result show that perceived ease of use positively affect halal food SMEs intention to Use E-Money $(\beta=0.214, \mathrm{t}=2.104$, sig $<0.05)$. So it can be concluded that the Perceived ease of use affects the interest of halal food SMEs actors in using electronic money as payment tools in Surakarta. This implies that the perceived ease of use has a relationship with the intention of SMEs in using e-money. Such as, not difficult for users, easy installation stage, flexible, easy to learn and so on. The results supported by Made et al. (2016) which shows that the perceived ease of use has a positive and significant effect on the intention to use Mobile Commerce in Denpasar City. Difficulties in using the online system have become less noticed by MSME actors because the current e-money system is more user friendly. In addition, because online systems are more commonly used, people are becoming more competent in using them. On the marketing side, banks and financial institutions should highlight the functionality of their e-money systems so as to efficiently meet the banking needs of different users.

The Result of Hypotheses 3 show that Perceived Behavioral Control positively affect Halal Food SMEs intention to Use E-Money $(\beta=0.409, \mathrm{t}=3.257$, sig $<0.05)$. Ajzen, (1991) concluded that in predicting behavioral intentions, perceived control over behavior has a high degree of accuracy. The significant result of these study is consistent with the previous study (Khatimah \& Halim, 2016; Taylor \& Todd, 1995). The results of this study indicate that a 


\section{$A I C \overline{I E B}$ Annual International Conference \\ on Islamic Economics and Business, 2021}

person's confidence in using e-money can affect the perception of SMES actors on behavioral control and then affect the intention to use technology which will affect the use of e-money.

The forth hypotheses show that trust has positive and not significant influence to the halal food SMEs intention to use E-Money $(\beta=0.116, t=1.152$, sig $>0.05)$. The possible reason for this unsignificant result is the halal food SMEs actor tend to believe that cash money the received from customer more reliable better than e-money which is not visible. The unsignificant result of these study is consistent with the previous study (Abdul-Hamid et al., 2019).

This study has practical importance for banks that currently offer banking services as well as banks that plan to offer e-money services. For example, in promoting the Internet, because currently customers rely more on their own efforts to seek information than to obtain references from the bank, banks offering Internet services must carry out campaigns to direct their customers. Issues such as safety and security in using shared banking services can be focused on educating potential customers.

In building a risk-free online transaction environment is more difficult than providing benefits to customers. Therefore, online banking companies need to look for strategies that can reduce risk so that they can gain high trust from potential customers.

This study shows that online banking companies can develop trust-building mechanisms to attract customers, such as assurance statements, increased familiarity through advertising, and long-term customer service. It should be noted that online banking is a less controllable environment so online banking customers usually have difficulty requesting compensation when a transaction error occurs.

\section{Conclusion}

Based on the results of the study, it can be concluded that perceived usefulness, perceived ease of use and perceived behavioral control are supported to have an effect on halal food SMEs intention to use E-money. Meanwhile, trust is unsupported to have an effect on halal food SMEs intention to use E-money. In understanding the nature of the halal food SMEs intention to use e-money, this study is expected to contribute to the SMEs knowledge in using e-money. The information expects to helpful in explaining the theory underlying e-money and consumer behavior from SMEs perspective.

Bank Indonesia as the regulator of non-cash payment transactions in Indonesia, must begin to regulate electronic money EDC (electronic data capture) tools so that they can be used by all types of electronic money. In order to create convenience for SMEs in using emoney.

Future research is expected to focus on the factors that influence the use of e-money in accordance with the sharia principle. E-money is a new thing in the financial industry so that its application is not yet clearly stated in the Qur'an. Muslim SMEs who are encouraged to use e-money still have doubts about whether this is in accordance with shariah principles.

\section{References}

Abdul-Hamid, I. K., Shaikh, A. A., Boateng, H., \& Hinson, R. E. (2019). Customers' perceived risk and trust in using mobile money services-an empirical study of Ghana. International Journal of E-Business Research, 15(1), 1-19. https://doi.org/10.4018/IJEBR.2019010101

Ahmad, \& Pambudi, B. S. (2013). Pengaruh Persepsi Manfaat, Persepsi Kemudahan, Keamanan Dan Ketersediaan Fitur Terhadapminat Ulang Nasabah Bank Dalam Menggunakan Internet Banking (Studi Pada Program Layanan Internet Banking Bri). 


\section{$A T C$ Annual International Conference \\ on Islamic Economics and Business, 2021}

Journal of Chemical Information and Modeling, 53(9), 1689-1699. https://doi.org/10.1017/CBO9781107415324.004

Ajzen, I. (1991). The Theory of Planned Behavior. In Organizational Behavior And Human Decision Processes (Vol. 50).

Ajzen, I. (2006). Behavioral Interventions Based on the Theory of Planned Behavior.

Ajzen, I., \& Fishbein, M. (1970). The Prediction of Behavior from Attitudinal and Normative Variables1. In Journal Of Expe Rimental Social Psychology (Vol. 6).

Ajzen, I., \& Fishbein, M. (1975). A Bayesian Analysis of Attribution Processes. In Psychological Bulletin (Vol. 82, Issue 2).

Ba, S., \& Pavlou, P. A. (2002). Evidence of the Effect of Trust Building Technology in Electronic Markets: Price Premiums and Buyer Behavior. MIS Quarterly, 26(3), 243. https://doi.org/10.2307/4132332

Davis, F. D. (1989). Perceived Usefulness, Perceived Ease of Use, and User Acceptance of Information Technology. MIS Quarterly, 13(3), 319. https://doi.org/10.2307/249008

Davis, F. D., Bagozzi, R. P., \& Warshaw, P. R. (1989). User Acceptance of Computer Technology: A Comparison of Two Theoretical Models. Management Science, 35(8), 982-1003. https://doi.org/10.1287/mnsc.35.8.982

Firmansyah. (2018). Uang Elektronik Dalam Perspektif Islam. CV IQRO.

Jogiyanto. (2007). Sistem Informasi Keperilakuan. Penerbit Andi.

Khatimah, H., \& Halim, F. (2016). The effect of attitude and its decomposed, perceived behavioral control and its decomposed and awareness on intention to use e-money mobile in Indonesia. Journal of Scientific Research and Development, 3(1), 39-50. www.jsrad.org

Made, N., Puspita, A., \& Warmika, I. G. K. (2016). Peran persepsi kemudahan penggunan, persepsi manfaat dan perspsi resiko terhadap niat menggunakan. 5(4), 2606-2636.

Prayitno, A. L. R. dan D. H. (2018). Persepsi Manfaat Terhadap Minat Nasabah Dalam Menggunaan E-Money Pada Bank Bri Lamongan. III(2), 699-711.

Priambodo, S., \& Prabawani, B. (2016). Pengaruh Persepsi Manfaat, Persepsi Kemudahan Penggunan, Dan Persepsi Risiko Terhadap Minat Menggunakan Layanan Uang Elektronik (Studi Kasus Pada Masyarakat Di Kota Semarang). Jurnal Ilmu Administrasi Bisnis, 5(2), 127-135.

Ramadhan, A. F., Prasetyo, A. B., \& Irvania, L. (2016). Persepsi Mahasiswa Dalam Menggunakan E-Money. Jurnal Ekonomika \& Bisnis, 13(2).

Romadloniyah, A. L., \& Prayitno, D. H. (2018). Pengaruh Persepsi Kemudahan Penggunaan, Persepsi Daya Guna, Persepsi Kepercayaan, Dan Persepsi Manfaat Terhadap Minat Nasabah Dalam Menggunaan E-Money Pada Bank Bri Lamongan. Jurnal Akuntansi, 3(3), 699. https://doi.org/10.30736/jpensi.v3i3.163

Sari, R. P., \& Santoso, D. T. (2019). Pengembangan Model Kesiapan UMKM di Era Revolusi Industri 4.0. In Jurnal Media Teknik \& Sistem Industri (Vol. 3, Issue 1). http://jurnal.unsur.ac.id/index.php/JMTSI

Seng, L. C., \& Ping, N. S. (2016). The Influence of Product Innovation Toward Consumer Purchase Intention. International Journal of Economics, Commerce and Management, 5(4), 773-782.

Taylor, S., \& Todd, P. A. (1995). Understanding information technology usage. Information Systems Research, 6(2), 144-176.

Terry, D. J., \& O'Leary, J. E. (1995). The theory of planned behaviour: The effects of perceived behavioural control and self-efficacy. British Journal of Social Psychology, 34(2), 199-220. https://doi.org/10.1111/j.2044-8309.1995.tb01058.x

Tonglet, M., Phillips, P. S., \& Read, A. D. (2004). Using the Theory of Planned Behaviour to investigate the determinants of recycling behaviour: a case study from Brixworth, UK. Resources, Conservation and Recycling, 41(3), 191-214. 


\section{$A I \overline{I F B}$ Annual International Conference \\ on Islamic Economics and Business, 2021}

https://doi.org/10.1016/j.resconrec.2003.11.001

Wibowo, S. F., Rosmauli, D., \& Suhud, U. (2015). Pengaruh Persepsi Manfaat, Persepsi Kemudahan, Fitur Layanan, Dan Kepercayaan Terhadap Minat Menggunakan EMoney Card (Studi Pada Pengguna Jasa Commuterline Di Jakarta). JRMSI - Jurnal Riset Manajemen Sains Indonesia, 6(1), 440-456. https://doi.org/10.21009/JRMSI.006.1.06

Widyastuti, K., Handayani, P. W., \& Wilarso, I. (2017). Tantangan dan Hambatan Implementasi Uang Elektronik di Indonesia: Studi Kasus PT XYZ. Jurnal Sistem Informasi, 13(1), 38. https://doi.org/10.21609/jsi.v13i1.465 